\title{
Novel cell-wall teichoic acid from Nocardiopsis albus subsp. albus as a species-specific marker
}

\author{
Elena M. Tul'skaya, ${ }^{1}$ Alexander S. Shashkov, ${ }^{2}$ Ludmila I. Evtushenko, ${ }^{3}$ \\ Victoriya V. Taran ${ }^{3}$ and Irina B. Naumova'
}

Author for correspondence: I. B. Naumova. Fax: +70959394309.

1 Department of Biology, Moscow State University, Moscow 119899, Russia

2 N. D. Zelinsky Institute of Organic Chemistry, Russian Academy of Sciences, Moscow, Russia

3 Institute of Biochemistry and Physiology of Microorganisms, Russian Academy of Sciences, Pushchino, Moscow Region, Russia

\begin{abstract}
Cell walls of the three Nocardiopsis albus subsp. albus strains, DSM $43377^{\top}$, 43378 and $\mathbf{4 3 1 2 0}$ contain structurally identical teichoic acids. The cell wall of each strain has three distinct types of teichoic acids: (1) unsubstituted 3,5poly(ribitol phosphate), (2) 1,3-poly(glycerol phosphate) partially substituted at C-2 with $\alpha$-N-acetylglucosamine residues, and (3) 1,5-poly(ribitol phosphate) with each ribitol unit carrying a 2,4-pyruvate ketal group. Types 1 and 3 are reported in prokaryotes for the first time. The structure of the teichoic acids was elucidated by chemical analysis and NMR-spectroscopic methods. Structural identity of the teichoic acids from the three strains belonging to the same species may demonstrate the species-specificity of these polymers.
\end{abstract}

Keywords: Nocardiopsis, cell walls, teichoic acids, 3,5-poly(ribitol phosphate), pyruvic acid, NMR spectroscopy

\section{INTRODUCTION}

The genus Nocardiopsis belonging to the order Actinomycetales was segregated from the genus Actinomadura based on morphological features and cell wall composition (Meyer, 1976). Later, the heterogeneity of this genus was demonstrated (Grund \& Kroppenstedt, 1990), and some Nocardiopsis species were transferred into the genus Saccharotbrix proposed by Labeda et al. (1984).

The genus Nocardiopsis comprises seven species including $N$. dassonvillei and $N$. albus subsp. albus (Altai \& Ruan, 1994). Earlier, we studied the cell-wall teichoic acid from 15 strains of $N$. dassonvillei and showed that all the strains contained the same polymers of unique structure, hitherto never found in bacterial cell walls (Tul'skaya et al., 1993; Akimov et al., 1994).

The same teichoic acids were also found in $N$. antarcticus and N. albus subsp. prasina which show a high degree of DNA relatedness with the type strain $N$. dassonvillei and have been reclassified as members of that species (Akimov et al., 1994).

In this work we have investigated the structure of the cellwall teichoic acids from three strains of $N$. albus subsp. albus and obtained further evidence of species-specificity of these polymers.
Some preliminary information on the composition of the N. albus subsp. albus DSM 43120 cell wall was reported previously (Tul'skaya et al., 1995).

\section{METHODS}

Organisms. N. albus subsp. albus DSM 43377 $7^{\mathrm{T}}$, DSM 43378 and DSM 43120 were cultivated as described by Naumova et al. (1980).

Analytical procedures. Cell walls were prepared according to Gnilozub et al. (1994). Extraction and purification of teichoic acids, structural determination, molecular mass determination and other analytical procedures have been described previously (Naumova et al., 1990; Tul'skaya et al., 1991). Pyruvic acid was quantified according to Telegina (1980). The amount of periodate consumed during oxidation was quantified according to Dixon \& Lipkin (1954).

Ribitol content of the cell wall was assayed after hydrolysis of the wall with $40 \%(\mathrm{v} / \mathrm{v})$ aqueous $\mathrm{HF}$ at $20^{\circ} \mathrm{C}$ for $24 \mathrm{~h}$; glycerol was quantified after hydrolysis with $2 \mathrm{M} \mathrm{HCl}$ at $100^{\circ} \mathrm{C}$ for $5 \mathrm{~h}$ and subsequent treatment of the hydrolysate with phosphomonoesterase (EC 3.1.3.1, Sigma). Polyols were resolved by paper chromatography in system $B$ and quantified by measuring the amount of formaldehyde formed after periodate oxidation (Hanahan \& Olley, 1958).

Chromatography and electrophoresis. These were carried out on Filtrak FN-13 paper. Electrophoresis was run in the pyridine/acetate buffer A of Tul'skaya et al. (1991). The following solvent systems were used in descending paper chromatography: (B) butan-1-ol/pyridine/benzene/water $(5: 3: 1: 3$, by vol.) to separate polyols, glycosides and 
aminosugars; (C) pyridine/ethyl acetate/acetic acid/water (5:5:1:3, by vol.) to separate aminosugars; (D) propan-1$\mathrm{ol} / 2 \mathrm{M} \mathrm{NH}_{4} \mathrm{OH}(7: 3, \mathrm{v} / \mathrm{v})$ and (E) amyl alcohol/5 $\mathrm{M}$ formic acid $(1: 1, \mathrm{v} / \mathrm{v})$ to identify pyruvic acid.

To detect the compounds, the following spray reagents were used: the reagent of Isherwood for phosphorus-containing compounds, $5 \%(\mathrm{w} / \mathrm{v}) \mathrm{AgNO}_{3}$ in aqueous $\mathrm{NH}_{3}$ for polyols, glycosides and glucosamine; ninhydrin for glucosamine; aniline xylose (Hais \& Macek, 1958) to identify pyruvic acid.

NMR. ${ }^{13} \mathrm{C}$ and ${ }^{1} \mathrm{H}$ NMR spectra of the teichoic acids solutions were recorded under the conditions described previously (Gnilozub et al., 1994). The ${ }^{1} \mathrm{H}-\mathrm{NMR}$ and ${ }^{13} \mathrm{C}-\mathrm{NMR}$ spectra were recorded with a Brucker WM-250 and a AM-300 respectively, at $60^{\circ} \mathrm{C}$ with acetone as internal standard $\left(\delta_{\mathrm{H}}=2.225\right.$ p.p.m., $\delta_{\mathrm{C}}=31.45$ p.p.m. $)$. Two-dimensional ${ }^{1} \mathrm{H}$ nuclear Overhauser effects (nOe) in rotating frames (Shashkov et al., 1994) were obtained using a standard Brucker program from the software package for the Aspect 3000 computers for ROESY. The HMQC spectrum (Bax \& Subramanian, 1986) was taken with the AM-300 spectrometer without suppression proton-carbon coupling constants and using a standard Brucker program.

\section{RESULTS AND DISCUSSION}

Results of the studies on the teichoic acids from three strains are described. Except for the quantitative differences discussed below, the results were identical with all strains.

Teichoic acid was obtained by extraction of the cell walls with $10 \%$ trichloroacetic acid. To prevent possible contamination with lipoteichoic acid, cell walls were treated with SDS before extraction. Acid hydrolysates of the preparation contained glycerol, ribitol, phosphorus, glucosamine, and pyruvic acid. This implied the possible presence of several teichoic acids. This conclusion was substantiated by the results of the electrophoretic analysis of the preparation in buffer A. Three phosphoruscontaining zones were detected.

Efforts to use preparative electrophoresis to completely resolve the zones and to accumulate amounts sufficient for further analysis failed. Therefore, in the subsequent work, the preparation isolated from the crude fat-free mycelium by extraction with $10 \%$ trichloroacetic acid (Archibald, 1972) was used throughout. Teichoic acids were separated and purified by ion-exchange chromatography on a DEAE-Toyopearl $650 \mathrm{M}$ column in a linear $\mathrm{NaCl}$ gradient $(0-0.5 \mathrm{M})$. Three phosphorus-containing fractions were eluted: fraction 1 at $0 \cdot 16-0 \cdot 19 \mathrm{M} \mathrm{NaCl}$; fraction 2 at $0.22 \mathrm{M} \mathrm{NaCl}$; and fraction 3 at $0.27-0.30 \mathrm{M} \mathrm{NaCl}$. Each fraction was pooled, dialysed against deionized water, lyophilized, and analysed separately.

\section{Fraction 1}

Qualitative analysis of this fraction revealed the presence of ribitol and phosphorus. Acid hydrolysis yielded ribitol mono- and diphosphates. The same esters were detected as the products of the alkaline hydrolysis of the polymer.

The results of acid and alkaline degradations suggested that the polymer was an unsubstituted poly(ribitol phos- phate). In all poly(ribitol phosphates) from the bacterial cell walls described hitherto, ribitol units are joined by phosphodiester bonds involving C-1 and C-5 hydroxy groups (1,5-type). On periodate oxidation of polymers of this type, formaldehyde is formed only from the terminal ribitol residue (Armstrong et al., 1961). However, periodate oxidation of the polymer resulted in the formation of formaldehyde in an amount equimolar to phosphorus content. This was interpreted as evidence of a different position of the phosphodiester bond.

In the course of polymer biosynthesis, D-ribitol-5-phosphate moieties originating from the nucleotide precursor are transferred to a growing polymer chain (Baddiley, 1972). Therefore, formation of the phosphodiester bond should necessarily involve the ribitol C-5 hydroxy group. Assuming that the other hydroxy group forming the phosphodiester bond is located at C-4 or C-3, one should expect formation of 1 mole of formaldehyde for each ribityl residue making up the polymer chain.

One mole of $\mathrm{NaIO}_{4}$ per mole phosphate was consumed during oxidation of the polymer. The only explanation of this result is that the hydroxy group at C-3 of ribitol is involved in phosphodiester bond formation.

The polymer structure was independently examined by NMR spectroscopy. The ${ }^{13} \mathrm{C}-\mathrm{NMR}$ spectrum (Fig. 1, Table 1) contained five main signals and several minor signals derived from the contaminating fraction 2 (see below). Some of the main signals had the characteristic splitting at phosphorus atoms. The presence of five signals was evidence of the asymmetrical substitution of ribitol. The APT spectrum (Patt \& Shoolery, 1982) showed that the signals at 68.3 p.p.m. and 64.0 p.p.m. could be assigned to $\mathrm{CH}_{2}$ groups, and the other three to $\mathrm{CH}$ groups. The downfield position of signals at 68.3 p.p.m. $\left(\mathrm{CH}_{2} \mathrm{O}\right)$ and 78.6 p.p.m. $(\mathrm{CHO})$ indicated that they belonged to the carbon atoms substituted with phosphate groups. The signal from one of the $\mathrm{CH}_{2}$ groups shifted upfield ( $64 \cdot 0$ p.p.m.) had no characteristic splitting due to the phosphorus atom which ruled out the 2,5 type of phosphodiester linkage. However, consistent with the 3,5 type of linkage, all the signals from the $\mathrm{CH}$ groups were split. If the phosphodiester bond had linked the $\mathrm{OH}$ groups at C-4 and C-5, the signal from C-2 would not have been split. Pseudo-triplet splitting of the signal from C-4 due to interaction with two phosphorus atoms provided additional indication of the ribitol residue being substituted at positions 3 and 5.

Thus, teichoic acid 1 is an unsubstituted 3,5-poly(ribitol phosphate). The molecular mass of the teichoic acid was determined by Sephadex G-50 gel filtration chromatography using reference teichoic acids and found to be about $5600 \mathrm{Da}$. This suggests a chain length of about 26-27 ribitol phosphate units (Fig. 2).

\section{Fraction 2}

Acid hydrolysis of fraction 2 yielded glycerol mono- and diphosphates, glucosamine, glycerol and inorganic phosphate. Alkaline hydrolysis of the polymer yielded glycerol 


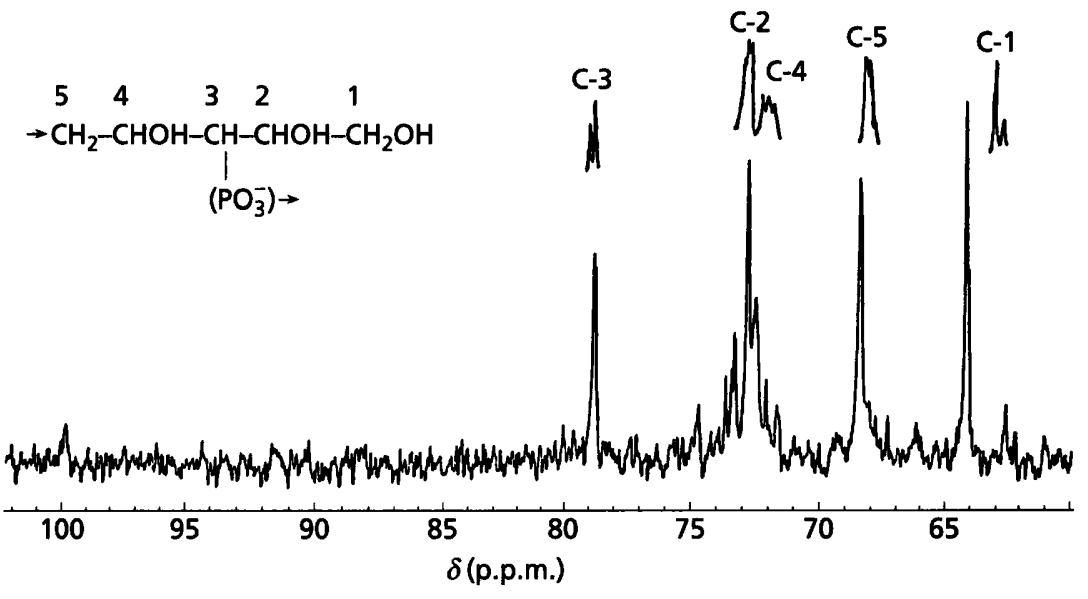

Fig. $1 .{ }^{13} \mathrm{C}-\mathrm{NMR}$ spectrum of teichoic acid 1 from the cell wall of $N$. albus subsp. albus DSM 43120. Expanded signals are shown above. The spectrum contains minor signals arising from contamination with teichoic acid 2 .

Table 1. Chemical shifts of carbons in the ${ }^{13} \mathrm{C}$ spectra of cell-wall teichoic acid from N. albus subsp. albus

The coupling constants ${ }^{2} J_{\mathrm{P}, \mathrm{C}}$ and ${ }^{3} J_{\mathrm{P}, \mathrm{C}}$ (in $\mathrm{Hz}$ ) are shown in parentheses.

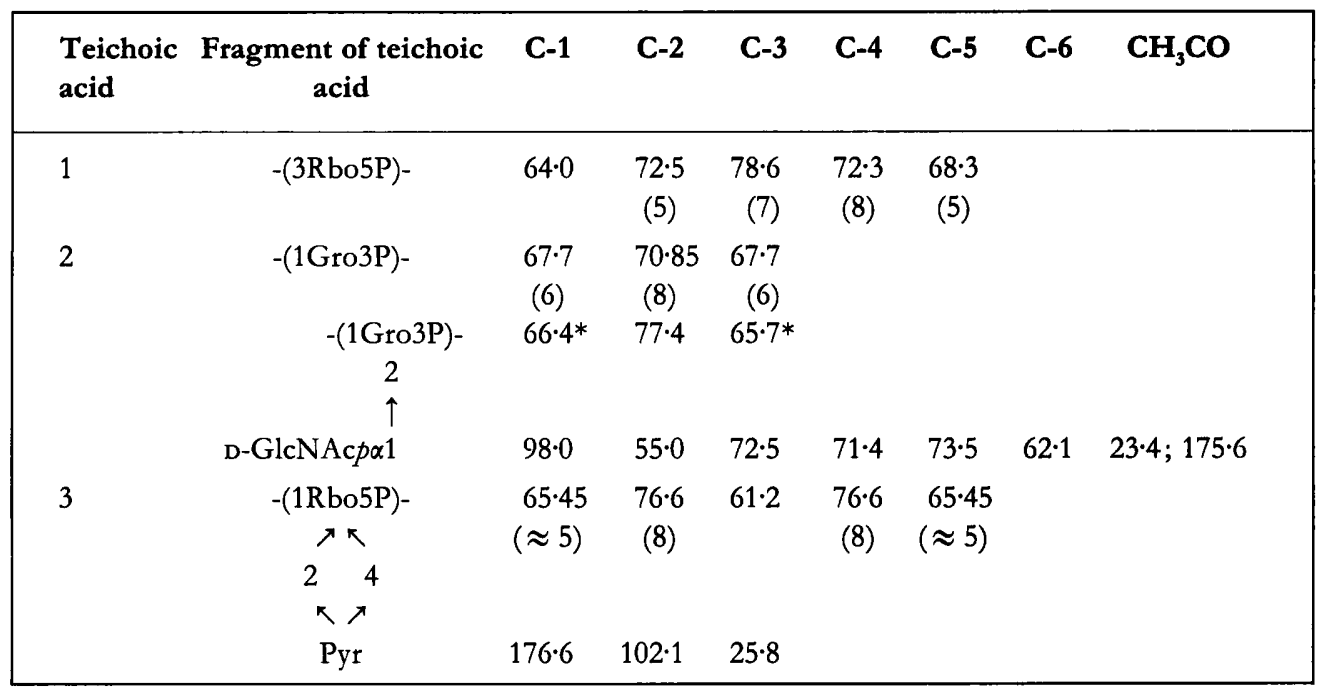

* Arbitrary assignment.

mono- and diphosphates, glycerol and a small amount of glucosamine-containing glycerol phosphodiesters. Hydrolysis of the polymer with $40 \%$ aqueous $\mathrm{HF}$ yielded glycerol and a glycoside. The latter was accumulated by preparative paper chromatography in system $B$ and subjected to analysis. It displayed an $R_{\text {Gro }}$ of $0 \cdot 70$, was not stained with ninhydrin or aniline phthalate, yielded equimolar amounts of glycerol and glucosamine on acid hydrolysis $\left(6 \mathrm{M} \mathrm{HCl}, 100^{\circ} \mathrm{C}, 6 \mathrm{~h}\right)$, and no formaldehyde upon periodate oxidation. These results showed that the glucosamine was in the pyranose form, was linked via a glycoside bond to the secondary hydroxyl of glycerol, and had an $N$-acyl substituent. On the basis of these data the polymer under investigation was inferred to be a 1,3poly(glycerol phosphate) partially substituted at C-2 with $N$-acetylglucosamine. The molar ratio of the constituents P-Gro-GlcN in the polymer was $1 \cdot 0: 1 \cdot 06: 0 \cdot 08(1: 1: 0 \cdot 1)$.
The ${ }^{13}$ C NMR spectra were typical of the 1,3-poly(glycerol phosphate) partially substituted with $\alpha-N$-acetylglucosamine (Table 1) (Naumova et al., 1982).

The molecular mass of the polymer, estimated in the same way as that of polymer 1 was $7600 \mathrm{Da}$. Based on the molar content of the polymer constituents, this suggested a chain length of 40-41 glycerol phosphate units (Fig. 2).

Thus, teichoic acid 2 is a 1,3-poly(glycerol phosphate) with about $10 \%$ of glycerol phosphate units being substituted with $\alpha-N$-acetylglucosamine residues.

\section{Fraction 3}

Fraction 3 polymer was eluted from the column at high $\mathrm{NaCl}$ concentration $(0.3 \mathrm{M})$ suggesting a higher negative charge as compared to the fraction 1 and 2 polymers. 


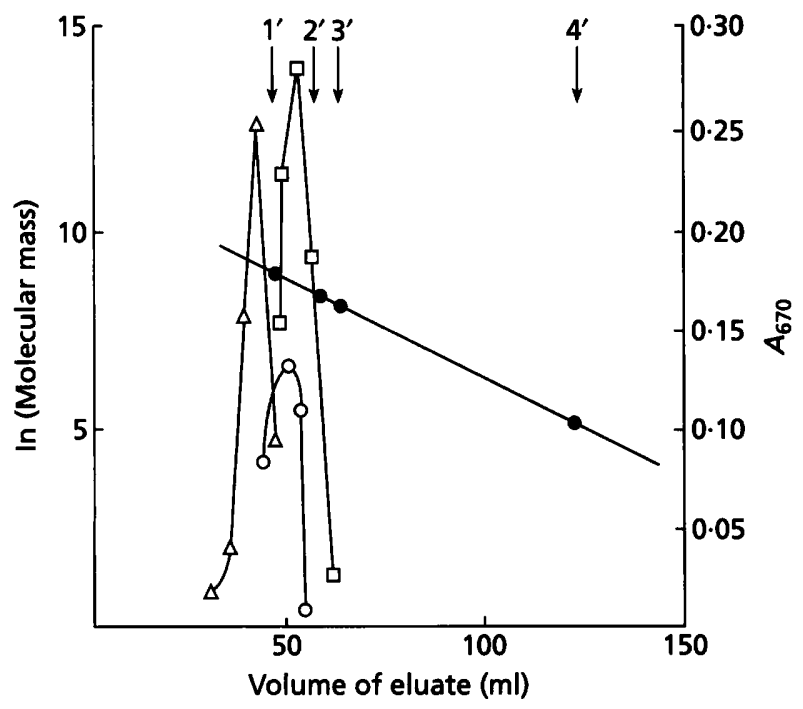

Fig. 2. Chromatography of cell-wall teichoic acids from $N$. albus subsp. albus on a Sephadex G-50 column $(990 \mathrm{~mm} \times 9.5 \mathrm{~mm}$; fraction volume $2 \mathrm{ml}$ ). 0 , Teichoic acid 1; $\triangle$, teichoic acid 2; $\square$, teichoic acid 3. Molecular mass standards (O): 1', teichoic acid from Streptomyces antibioticus (7000 Da) (Shashkov et al., 1979); 2', teichoic acid from $S$. violaceus (4000 Da) (Naumova et al., 1969); 3', teichoic acid from S. azureus (3300 Da) (Streshinskaya et al., 1981); 4', glycerol monophosphate.

Electrophoretic behaviour of the polymer was in agreement with this conclusion $\left(E_{\mathrm{GroP}} 1 \cdot 96\right)$. Acid hydrolysis of the polymer yielded ribitol mono- and diphosphates, ribitol, inorganic phosphate and pyruvic acid. The latter was identified by comparison with an authentic sample using paper chromatography in systems D and E. Glycoside substituents were not detected. Alkaline hydrolysis and periodate oxidation did not degrade the polymer.
Table 2. Data from 'H NMR spectra of teichoic acid 3

\begin{tabular}{|lclr|}
\hline Proton & $\begin{array}{c}\text { Chemical } \\
\text { shift } \\
(\delta, \text { p.p.m. })\end{array}$ & $\begin{array}{c}\text { Coupling } \\
\text { constant } \\
(J, \mathbf{H z})\end{array}$ \\
\hline H-1a, H-5a & $4 \cdot 23$ & $J_{1 \mathbf{a}, 1 \mathrm{~b}}$ & $12 \cdot 5$ \\
H-1b, H-5b & $4 \cdot 17$ & $J_{1 \mathbf{b}, \mathbf{2}}$ & $4 \cdot 5$ \\
H-2, H-4 & 3.88 & $J_{1 \mathrm{a}, 2}$ & $2 \cdot 5$ \\
H-3 & 3.81 & $J_{2,3}$ & $9 \cdot 5$ \\
$\mathrm{CH}_{3}$ & 1.54 & & \\
\hline
\end{tabular}

Ribitol mono- and diphosphate formation on acid hydrolysis suggested that the teichoic acid was poly(ribitol phosphate). The resistance of the polymer to alkaline hydrolysis indicated the absence of free hydroxyl groups in the vicinity of phosphodiester groups (Kelemen \& Baddiley, 1961), while resistance to periodate oxidation was indicative of the absence of non-substituted glycol groups in the polymer. It was conceivable that ribitol residues were substituted with pyruvic acid bound via an alkali-stable ketal bond (Thurow et al., 1975). The complete removal of pyruvate was achieved within $3 \mathrm{~h}$ on acid hydrolysis $\left(2 \mathrm{M} \mathrm{HCl}, 100^{\circ} \mathrm{C}\right)$. The polymer released only $10 \%$ of its pyruvic acid under conditions $(2 \mathrm{M} \mathrm{HCl}$, $4 \mathrm{~h}, 100^{\circ} \mathrm{C}$ ) employed previously (Thurow et al., 1975) to completely hydrolyse the 4,6-ketal of its pyruvic acid and galactose.

The stability of the bond formed by pyruvate with ribitol prevented removal of the substituent without hydrolysis of the polymer chain. This, in turn, prevented determination of the localization of both the phosphodiester link and pyruvate.

The polymer was analysed by NMR spectroscopy. The ${ }^{13} \mathrm{C}$ NMR spectrum contained six main signals, two of
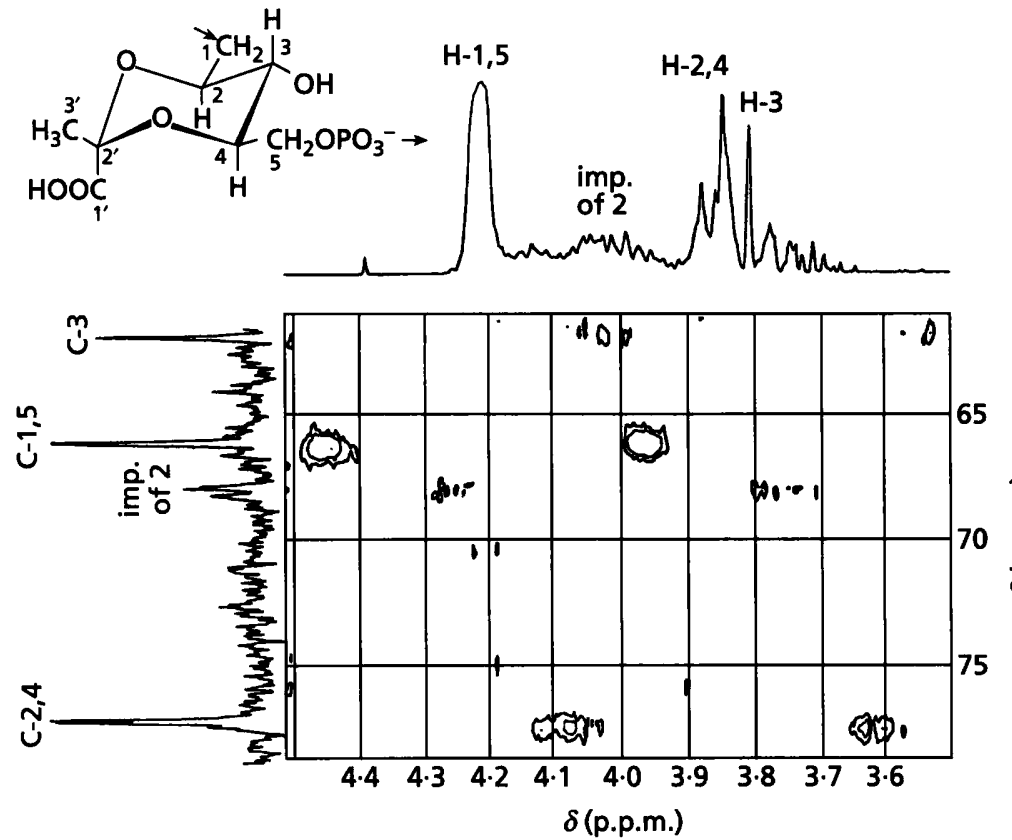

Fig. 3. HMQC spectrum of teichoic acid 3 from the cell wall of $N$. albus subsp. albus DSM 43120. One-dimensional ${ }^{13}$ C-NMR spectrum of teichoic acid 3 is shown on the left. Signals from $\mathrm{CH}_{3}$ at 25.8 p.p.m., from quaternary carbon atom at 102.1 p.p.m., and from $C=0$ at 176.6 p.p.m. are not shown. The spectrum contains minor signals arising from contamination with teichoic acid 2 (imp. of 2). 
Table 3. Phosphorus, polyols and pyruvic acid contents and chain ratios of teichoic acids in the cell wall of $N$. albus subsp. albus

\begin{tabular}{|c|c|c|c|c|c|c|c|}
\hline \multirow[t]{2}{*}{ Strain } & Phosphorus & Ribitol & Glycerol & $\begin{array}{l}\text { Pyruvic } \\
\text { acid }\end{array}$ & \multicolumn{3}{|c|}{$\begin{array}{l}\text { Chain } \\
\text { ratio }\end{array}$} \\
\hline & \multicolumn{4}{|c|}{$\mu \mathrm{mol}(100 \mathrm{mg} \text { cell wall })^{-1}$} & 1 & 2 & 3 \\
\hline DSM $43377^{\mathrm{T}}$ & 114.9 & $50 \cdot 7$ & $60 \cdot 2$ & $32 \cdot 4$ & 4 & 8 & 10 \\
\hline DSM 43378 & $100 \cdot 3$ & $58 \cdot 8$ & $37 \cdot 8$ & $30 \cdot 6$ & 6 & 5 & 10 \\
\hline DSM 43120 & $99 \cdot 6$ & $66 \cdot 2$ & $29 \cdot 6$ & $31 \cdot 4$ & 8 & 4 & 10 \\
\hline
\end{tabular}

which were of double integral intensity and were either broadened or split due to interaction with phosphorus atoms (Fig. 3). Three signals at 25.8 p.p.m. $\left(\mathrm{CH}_{3}\right)$, $102 \cdot 1$ p.p.m. (quaternary carbon atom), and $176 \cdot 6$ p.p.m. (CO) were unequivocally identified as belonging to a pyruvic acid residue in a six-membered ring (Garegg et al., 1980). Hence, the other three signals, including the two of double intensity mentioned above belonged to the five carbon atoms of the ribitol residue. This was evidence of symmetrical substitution of ribitol residues with pyruvate. Broadening of the signal at 65.45 p.p.m. $\left(\mathrm{CH}_{2}\right.$ group, APT-spectrum) and splitting of the signal at 76.6 p.p.m. were indicative of a 1,5-poly(ribitol phosphate) chain.

Additional evidence of the polymer structure was furnished by the ${ }^{1} \mathrm{H}$ NMR spectrum. The polymer proton spectrum contained the singlet of the $\mathrm{CH}_{3}$ group of pyruvate at 1.54 p.p.m. (Table 2) and three series of peaks with the integral intensity ratio $1: 2: 4$. These signals were assigned using homonuclear double resonance. The magnitudes of the coupling constants were typical of an axial orientation of all the protons in the six-membered ring.

As shown in Table 1, two-dimensional homonuclear ${ }^{1} \mathrm{H} /{ }^{13} \mathrm{C}$ spectrum (HMQC) (Bax \& Subramanian, 1986) (Fig. 3) confirmed the assignment of the signals in the carbon spectrum. The downfield position of the signal from the $\mathrm{CH}_{3}$ group of pyruvate was unequivocal evidence of an equatorial orientation in the six-membered ring (Garegg et al., 1980). Therefore, the repeating unit of the polymer has the structure depicted in Fig. 3.

The molecular mass of the polymer estimated in the same way as that of polymers 1 and 2 was about $5400 \mathrm{Da}$ corresponding to a chain length of about 18 repeating units (Fig. 2).

To assess the amounts of these polymers in the cell walls of the three strains under study, glycerol and ribitol were quantified (Table 3 ). In a preliminary experiment, treatment of the cell wall with $40 \%$ aqueous $\mathrm{HF}\left(24 \mathrm{~h}, 20^{\circ} \mathrm{C}\right)$ was shown to result in a complete cleavage of the ketal bond. Based on the content of ribitol and pyruvic acid in the cell walls and taking into account the complete substitution of polymer 3 with pyruvate, the proportions of polymers 1 and 3 were estimated. Knowing a polymer chain length, one can calculate the ratio of the teichoic acid chains in the cell walls. Cell walls of the strains differed quantitatively in the content of the three teichoic acids (Table 3).

Thus, the cell wall of Nocardiopsis albus subsp. albus contains three structurally distinct teichoic acids. 3,5poly(ribitol phosphate) and pyruvylated 1,5-poly(ribitol phosphate) are reported in prokaryotes for the first time. Pyruvic acid was reported as a component of mannitol teichoic acid isolated from Brevibacterium iodinum NCTC 9742 cell wall (Anderton \& Wilkinson, 1980). 1,3Poly(glycerol phosphate) with $\alpha$ - $N$-acetylglucosaminyl substituents was previously described in the cell wall of a Streptomyces species (Naumova et al., 1982).

The bacterial cell wall is known to be structurally heterogeneous (Graham \& Beveridge, 1994). This heterogeneity may stem from the structural variability of cell wall teichoic acids. Being non-uniformly localized in the cell wall, these teichoic acids would perform different physiological functions, in particular furnishing both autolysin-sensitive and -resistant areas and making up domains with different anionic properties.

The fact that each of the three strains of $N$. albus subsp. albus examined has an identical set of cell wall teichoic acids taken together with the recent observation on the structure of the teichoic acids from $N$. dassonvillei strains (Tul'skaya et al., 1993; Akimov et al., 1994) may serve as an indication of species-specificity of these polymers in the genus Nocardiopsis.

\section{ACKNOWLEDGEMENT}

The study was supported by the Russian Fund for Fundamental Investigations (N 93-03-5839 and N 95-04-11997) and a 'Universities of Russia' grant (N 231-31).

\section{REFERENCES}

Akimov, V. N., Taran, V. V., Evtushenko, L. I., Naumova, I. B. \& Kalakoutskii, L. V. (1994). Grouping of Nocardiopsis strains on the basis of DNA relatedness. In The 9th International Symposium on the Biology of Actinomycetes (Theses), P 3-34, p. 242. July 10-15, Moscow, Russia. 
Altai, A. M. \& Ruan, J. S. (1994). Nocardiopsis balophilus sp. nov., a new halophilic actinomycete isolated from soil. Int J Syst Bacteriol 44, 474-478.

Anderton, W. J. \& Wilkinson, S. G. (1980). Evidence for the presence of a new class of teichoic acid in the cell wall of bacterium NCTC 9742. J Gen Microbiol 118, 343-351.

Archibald, A. R. (1972). Teichoic acids. Methods Carbobydr Chem 6, 162-172.

Armstrong, J. J., Baddiley, J. \& Buchanan, J. G. (1961). Further studies on the teichoic acid from Bacillus subtilis walls. Biocbem $J \mathbf{8 0}$, 254-261.

Baddiley, J. (1972). Teichoic acids in cell walls and membranes of bacteria. Essays Biochem 8, 35-77.

Bax, A. \& Subramanian, S. (1986). Sensitivity-enhanced twodimensional heteronuclear shift correlation NMR spectroscopy. J Magnet Reson 67, 565-569.

Dixon, J. S. \& Lipkin, D. L. (1954). Spectrophotometric determination of vicinal glycols. Application to the determination of ribofuranosides. Anal Chem 26, 1092-1093.

Garegg, P. J., Jansson, P. E., Lindberg, B., Lindh, F., Lönngren, J., Kvarnstrom, I. \& Nimmich, W. (1980). Configuration of the acetal carbon atom of pyruvic acid acetals in some bacterial polysaccharides. Carbobydr Res 78, 127-132.

Gnilozub, V. A., Streshinskaya, G. M., Evtushenko, L. I., Naumova, I. B. \& Shashkov, A. S. (1994). The 1,5-poly(ribitol phosphate) with tetrasaccharide substituents in the cell wall of Agromyces fucosus subsp. bippuratus. Biokbimiya 59, 1892-1899.

Graham, L. L. \& Beveridge, T. J. (1994). Structural differentiation of the Bacillus subtilis 168 cell wall. J Bacteriol 176, 1413-1421.

Grund, E. \& Kroppenstedt, R. M. (1990). Chemotaxonomy and numerical taxonomy of the genus Nocardiopsis Meyer 1976. Int $J$ Syst Bacteriol 40, 5-11.

Hais, I. M. \& Macek, K. (1958). Handbuch der Papierchromatograpbie, p. 739. Jena: Gustav Fischer Verlag.

Hanahan, D. J. \& Olley, J. N. (1958). Chemical nature of monophosphoinositides. J Biol Chem 231, 813-828.

Kelemen, M. V. \& Baddiley, J. (1961). Structure of the intracellular glycerol teichoic acid from Lactobacillus casei ATCC 7469. Biochem J 80, 246-254.

Labeda, D. P., Testa, R. T., Lechevalier, M. P. \& Lechevalier, H. A. (1984). Saccharotbrix: a new genus of Actinomycetales related to Nocardiopsis. Int J Syst Bacteriol 34, 426-431.

Meyer, J. (1976). Nocardiopsis, a new genus of the order Actinomycetales. Int J Syst Bacteriol 26, 487-493.
Naumova, I. B., Rogozina, S. V. \& Zaretskaya, M. Sh. (1969). On the structure of the cell wall teichoic acid from Actinomyces violaceus. Dok Akad Nauk 188, 710-712.

Naumova, I. B., Kuznetsov, V. D., Kudrina, K. S. \& Bezzubenkova, A. P. (1980). The occurrence of teichoic acids in Streptomyces. Arch Microbiol 126, 71-75.

Naumova, I. B., Shashkov, A. S., Skoblilova, N. K., Agre, N. S. \& Romanov, V. V. (1982). Lysylteichoic acid of the cell wall of Streptomyces roseoflavus var. roseofungini 1128. Bioorg Khim 8, 848-856.

Naumova, I. B., Yanushkene, N. A., Streshinskaya, G. M. \& Shashkov, A.S. (1990). Cell wall anionic polymers and peptidoglycan of Actinoplanes philippinensis VKM Ac-647. Arcb Microbiol 154, 483-488.

Patt, S. I. \& Shoolery, I. N. (1982). Attached proton test for carbon13 NMR. J Magnet Reson 46, 535-539.

Shashkov, A. S., Zaretskaya, M. Sh., Yarotsky, S. V., Naumova, I. B., Chizhov, O. S. \& Shabarova, Z. A. (1979). On the structure of the teichoic acid from the cell wall of Streptomyces antibioticus 39. Eur $J$ Biochem 102, 477-481.

Shashkov, A. S., Kochanowski, H., Kozlova, Yu. I., Streshinskaya, G. M., Naumova, I. B., Terekhova, L. P. \& Galatenko, O. A. (1994). Teichuronic acid of the cell wall of Actinoplanes brasiliensis. Biochim Biophys Acta 1201, 333-338.

Streshinskaya, G. M., Naumova, I. B., Romanov, V. V. \& Shashkov, A. S. (1981). Structure of ribitol teichoic acid from the cell wall of Streptomyces aqureus RIA 1009. Bioorg Kbim 7, 1410-1418.

Telegina, T. A. (1980). Quantity determination of pyruvic acid. In Biochemical Methods, pp. 154-157. Moscow: Nauka.

Thurow, H., Choy, Y. M., Frank, N. \& Niemann, H. (1975). The structure of Klebsiella serotype 11 capsular polysaccharide. Carbobydr Res 41, 241-255.

Tul'skaya, E. M., Vylegzhanina, K. S., Streshinskaya, G. M., Shashkov, A. S. \& Naumova, I. B. (1991). 1,3-Poly(glycerol phosphate) chains in the cell wall of Streptomyces rutgersensis var. castelarense VKM Ac-238. Biochim Biophys Acta 1074, 237-242.

Tul'skaya, E. M., Streshinskaya, G. M., Naumova, I. B., Shashkov, A. S. \& Terechova, L. P. (1993). A new structural type of teichoic acid and some chemotaxonomic criteria of two species Nocardiopsis dassonvillei and Nocardiopsis antarcticus. Arch Microbiol 160, 299-305.

Tul'skaya, E. M., Shashkov, A. S., Evtushenko, L. I., Taran, V. V. \& Naumova, I. B. (1995). The cell wall teichoic acids of Nocardiopsis albus subsp. albus DSM 43120. Biokbimiya 60, 179-186.

Received 5 January 1995; accepted 31 March 1995. 